\title{
Field Study of Gregarious Flowering and Use of ENM in Conservation Strategies for Gigantochloa andamanica (Kurz) Kurz in Andaman Islands (India)
}

\author{
${ }^{1}$ Pushpa Kumari, ${ }^{2}$ Reshma Lakra \\ 1,2Botanical Survey of India, Central National Herbarium, \\ P.O.: Botanic Garden, Howrah - 711103 (India) \\ Corresponding Author: pushparbg@gmail.com Mobile: +919434207721
}

\section{Manuscript Details}

Manuscript Submitted : 27/02/2019

Manuscript Revised : :04/03/2019

Manuscript Accepted : 08/03/2019

Manuscript Published : 15/03/2019

\section{$\underline{\text { Available On }}$}

https:/plantaescientia.website/ojs

\section{Cite This Article As}

Pushpa Kumari \& Reshma Lakra (2019). Field study of gregarious flowering and use of ENM in conservation strategies for Gigantochloa andamanica (Kurz) Kurz in Andaman Islands (India), Pla. Sci. 2019; Vol. 01 Iss. 06: 81-86. DOI: https://doi.org/10.32439/ps.vli06.81-86

\section{Copyright}

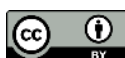

(c) The Author (s). 2019. Open Access This article is distributed under the terms of the Creative Commons Attribution 4.0 International License http://creativecommons.org/licenses/by/4.0/

$\underline{\text { Indexed In }}$

Crossref, Index Copernicus International (ICI), Directory of Research Journal Indexing (DRJI), Scientific Indexing Services (SIS), CiteFactor,

\begin{abstract}
Gregarious flowering in bamboo species is a periodic event which affects the habitat's ecology, since the whole population die within same time frame. The phenomenon sets effects on the social economy too as bamboo is one of the most important natural resources people depends on. In this paper gregarious flowering and mass seeding in Gigantochloa andamanica (Kurz) Kurz, an economically important bamboo species of Andaman Islands have been reported with effective conservation strategies to balance the population in natural habitat. This also includes the description, illustration, photo plates of the species for the easy identification, the ENM map based on the GPS data collected for the distribution area and data relevant to traditional and economic uses of the species. This study more importantly shows the application of ENM for the identification of suitable sites for field reintroduction of the seedlings in natural habitats aimed at their better growth and survival.
\end{abstract}

Keywords: Gigantochloa andamanica, gregarious flowering, seedlings, economic value, ENM, Andaman Islands. 


\section{INTRODUCTION}

Bamboo plays a significant role in environmental protection besides its economic values. The flowering cycle in bamboo has been a matter of much popular interest and speculation. Their flowering nature is usually of long interval and rare so that their identification is mostly done with their vegetative character. However for their correct generic placement floral characters are essential. Flowering records of a species reveal their flowering nature, pattern, time period, effect on ecosystem and many more. An event of massive flowering and seedling at intermittent intervals over a large area is common in woody bamboos. Flowering in bamboos may be sporadic or gregarious and vary from one species to another, generally it takes about $20-60$ years, sometimes even 120 years (McClure, 1966). The factors that determine gregarious flowering are not yet understood. Certain evidence points to the probability that a short rainy season followed by a spell of severe drought stimulates flowering (Gupta, 1952). In mast flowering, all members of a cohort (plants from seeds of common origin) or even an individual entering their productive phase simultaneously and subsequently die.

Gigantochloa andamanica (Kurz) Kurz is most utilised commercial bamboo found in many areas of Andaman Islands. During the year 2013 - 2019 flowering has been noticed in continuous range of occurrence of the species all over North to South Andaman. The clumps flower gregariously right through on the large area of its occurrence and finally die off altogether (Plate 2). This periodic flowering of bamboos once in a life span and its mass death event afterwards cause ecological disaster. This probably also explains why bamboo flowering is commonly associated with local feminine. The belief that flowering of bamboo omens disasters like famine and natural calamities has compelled the rural people to destroy the cohorts/clumps after or during blooming. Furthermore, the overexploitation of the bamboo plants added with mass scale death after gregarious flowering also enhance the extinction rate of the species, unless effective measures are taken for their conservation.

The systematic conservation of biodiversity requires knowledge of the spatial distribution of resources (Margules and Pressey, 2000). Field information on conservation aspects such as distribution, population status, habitat types, regeneration potential, causes of depletion of population size, and the level of disturbance to which the species is exposed to are fundamental. Ground surveys covering the entire study areas are much time consuming or not possible in most of the cases. However, knowledge of the areas where appropriate environmental conditions exist to sustain the species is a pre-requisite for species conservation. Thus, characterization of niche of species is fundamental to conservation biology. New Geographical Information System (GIS) approaches called Ecological Niche Modelling (ENM) are being used for the purpose which produces the potential distributional maps using maximum entropy modelling (MaxEnt 3.3.3e).

MaxEnt estimates the maximum entropy probability distribution function to predict the geographic location of a species based on environmental variables and reconstructs the boundaries of the ecological niche by placing constraints on the probability distribution based on the environmental parameters of the grid-cell presence record (Phillips et al. 2006). Ecological Niche Modelling was used for this study to construct the potential distribution of $G$. andamanica all over the Andaman Islands.

The area of study for this flowering event includes - North Andaman (Deshbandhu Gram, Kalara, Nabagram, Sitapur, Parangarah, Mohanpur); North-Middle Andaman (Mayabunder, Bamboonalah, Nimbutala); Middle Andaman (Rangat, Nimbutala, Bakultala, Panchvati, Parlobjig, Kadamtala, Shantanu); Middle-South Andaman (Jarawa creek, Mud volcano, Nayadera, Krishnanagar, Middle Straight); South Andaman (Middle Straight to Jirkatang, Pongibalu, Mount Harriet, Maanpur, Sholbay).

The GPS data of the collection sites are: North Andaman, Kalara, Lat. N1306'39.7" Long. E092 58'31.5", 28-12-2013; Middle Andaman, Khesredera, Lat. N12 23'24.2" Long E092 46 '46.5", 09-02-2014; South Andaman, Mount Harriet Lat. N11 45'07.1" Long. E092 45'07.1", 20-02-2014; South Andaman, Pongibalu, Lat. N11'31'31.2" Long. E092³6'39.4", 04-03-2014; South Andaman, Maanpur, Lat. N11 40'09.1 Long. E092 36'39.4", 06-03-2014; North Andaman, Kalara Lat. N13¹0'36.7" Long. E092 55'54.4", 07-04-2015; MiddleSouth Andaman, Mud volcano (Baratang), Lat. N12 $05^{\prime} 45.6$ Long. E092 44'39.2", 22-03-2015; South Andaman, Jirkatang Lat. N12 23'52.8" Long. E092 46'33.8", 22-03-2015; South Andaman, Sholbay, Lat. N11 $51^{\prime} 31.8^{\prime \prime}$ Long. E092 $44^{\prime} 07.9^{\prime \prime}, 28$ 12-2016; North Middle Andaman, Mayabunder, Lat $12^{\circ} 53^{\prime} 1.27^{\prime \prime}$ Long. 92 $52^{\prime} 24.3^{\prime \prime}, 18-12-2018$; North Andaman Parangarah, Lat. 138'40.24" Long. 9252'43.6", 05-12-2018.

\section{MATERIALS AND METHODS}

Specimens were collected and identified on the basis of their vegetative and reproductive characters and authenticated with available literature and herbarium. The illustrations for the morphological characters of the species have been done by examination of the live materials collected during the study and the description has been made with the help of the 
field notes taken as per the standard format used for bamboo collection and study of the samples under microscope in the laboratory. Flowering period of the species have been reported with the continuous field surveys in the distribution area, herbarium records and literature for earlier reports of flowering. Information of seedling growth and development were collected by observation and data recorded in the nursery, while that of economic value of the species has been brought out from the survey of local markets, tribal and the local inhabitant.

The conservation status through macro-proliferation and field reintroduction is under observation which is expected to be more than 60 percent. Distributional pattern of flowering and reintroduction sites is shown through ENM mapping (Mapl).The method of Ecological Niche Modelling (ENM) map is applied by using the modelling algorithms of DIVA-GIS and MAXENT. Nineteen bioclimatic variables are used as environmental variables for modeling, which includes Annual Mean Temperature, Mean Diurnal Range, Isothermality, Temperature Seasonality, Maximum Temperature of Warmest Month, Minimum Temperature of Coldest Month, Temperature Annual Range, Mean Temperature of Wettest Quarter, Mean Temperature of Driest Quarter, Mean Temperature ofWarmest Quarter, Mean Temperature of Coldest Quarter, Annual Precipitation, Precipitation of Wettest Month, Precipitation of Driest Month, Precipitation of Seasonality, Precipitation of Wettest Quarter, Precipitation of Driest Quarter, Precipitation of Warmest Quarter, Precipitation of Coldest Quarter etc. Through this modelling, the potential area of occurrences of the species and their reintroduction were done [Map 1].

Taxonomic identity of the species was confirmed with help of type, protologue, available herbarium specimens and the fresh samples collected from the field. All vegetative and reproductive parts of the plant were collected over a long period of time by visiting same locations in different seasons. This well-established species from Andaman Islands has been invalidly synonymized with another species of Gigantochloa in different works (Seethalakshmi and Kumar, 1998; Widjaja, 1987). Even the recently published work has treated this species under synonymy (Vorontsova et al., 2016). After critical and complete morphological study of all the parts of the species this is hereby retained as a taxonomic sound species.

Gigantochloa andamanica (Kurz) Kurz, Prelim. Rep. For. Pegu, 1875; Kurz, For. Fl. British Burma 2: 556. 1977. Bambusa andamanica Kurz in J. Asiat. Soc. Bengal n.s. 39(2): 88. 1870; The Bamboos of the world, Ohrnberger, 252. 1999. Vernacular name: 'Chataai bamboo'; 'Tennang'(Jarawas). [Fig. $1 \&$ Plate 1].

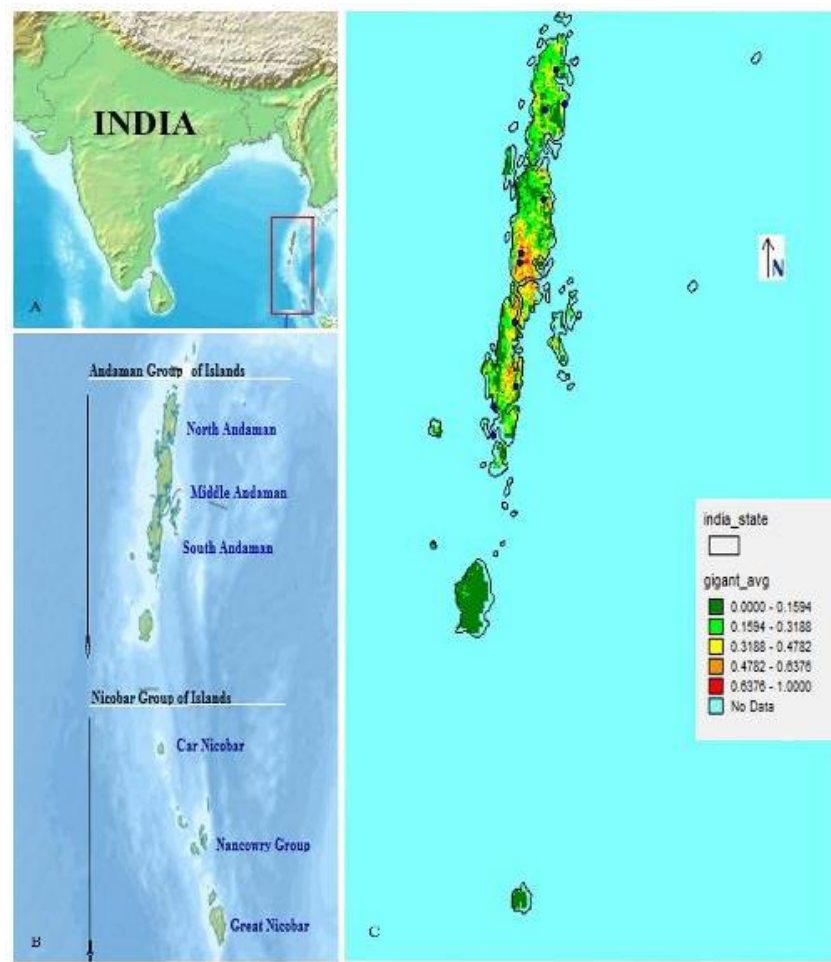

Map 1. : A. India map showing Andaman \& Nicobar Islands; B. Andaman \& Nicobar Islands; C. ENM map, warmer colours shows potential area of flowering, blue dots shows seedlings planted in habitats.

An evergreen densely clumped erect bamboo drooping above. Rhizome pachymorph. Culm $8-17 \mathrm{~m}$ tall, $4.5-6.5 \mathrm{~cm}$ in diameter, dark green when young, yellowish green when mature; nodal ring prominent; internodes $30-50 \mathrm{~cm}$ long, thin-walled, sometimes with longitudinal white stripes from base to middle; bud broadly ovate; branching in triplets, 3 12 from upper nodes. Culm sheaths late deciduous, elongated, shorter than internodes, brown, thin, crustaceous; sheath proper $12-32 \mathrm{~cm} \times 6-8 \mathrm{~cm}$ with appressed brownish black hair on outer surface, ciliate at upper margin; imperfect blade $3-5 \mathrm{~cm}$ long, lanceolate, shorter than sheath proper, pubescent within, deciduous; auricles elliptical, pointed, glabrous; ligule $2-3 \mathrm{~mm}$, entire. Leaves $6-16$ per twig, leaf blade $12-30 \times 4-6 \mathrm{~cm}$, broadly lanceolate, rounded to attenuate at base, acuminate at apex, glabrous, at times sparsely hairy on upper surface; midrib prominently raised, shining, glabrous, secondary veins $8-12$, tertiary veins $5-7$, no cross veins; margins minutely serrulate, ciliolate towards base; pseudopetiole $3-5 \mathrm{~mm}$ long, twisted at base, with few translucent hairs on adaxial side; leaf sheath prominently keeled, striate, appressed hairy, glabrous afterwards, ciliate margins, ending in $0.2-0.3 \mathrm{~mm}$, smooth callus; auricle oblong, prominently seen on one side, obscure on other side; ligule $0.3-0.5 \mathrm{~mm}$ long, entire, glabrous. Inflorescence panicle of spicate verticilis. Spikelets oval lanceolate, 3 -flowered, bisexual, $1.5-2.5 \mathrm{~cm} \times 2-3 \mathrm{~mm}$; empty glumes $3-4,4-8 \mathrm{~mm}$ long, broadly lanceolate or ovate, coriaceous yellowish brown, multi-veined, apex acute 
or shortly mucronate, margins ciliate, cilia golden brown; lemma $5 \mathrm{~mm}-2.3 \mathrm{~cm}$ long, lanceolate, coriaceous, yellowish brown, multi-veined, apex acuminate or mucronate, margins ciliate, cilia dark brown; palea $4 \mathrm{~mm}-1.2 \mathrm{~cm}$ long, linearlanceolate, apex bifid, 2-keeled, ciliate on keels, dorsal surface faintly pubescent, margins ciliate; anthers $6,2.8-8$ $\mathrm{mm}$ long, dark purple to pinkish purple, with hairy apex, filaments fused to form a $2-5 \mathrm{~mm}$ tube; ovary ovate, $1-2$ $\mathrm{mm}$ long, style $5 \mathrm{~mm}-1 \mathrm{~cm}$ long, stigma solitary, $1-2.5 \mathrm{~mm}$; caryopsis $1.2-1.5 \mathrm{~cm}$, elongate, golden brown, with persistent style.

Flowering cycle: The earlier available flowering evidence of this species is from Sundargarh, Baratang, South Middle Andaman in July 1977. Thus the estimated flowering cycle may be predicted as $38-40$ years for this species.

\section{Distribution: India: Andaman Islands; Myanmar, China,}

Hongkong, W. Malaysia (Ohrnberger, 1999; Vorontsova et al., 2016).

\section{Growth and Development of Seedlings}

Studies on the patches of flowering area reported during first rain, after $8-9$ month of flowering, germination of seeds started and just below the flowering mother clump, small seedlings could be seen. Seedlings with $6.39 \pm 1.08 \mathrm{~cm}$ shoot height were collected at 2 to 3 leaves stage without damaging the rhizome since, damaged rhizome leads to failure of propagation (Table l).

Collected seedlings (200 nos.) were transferred to the nursery for macro-proliferation / multiplication. Seedlings were transplanted into $40 \times 50 \mathrm{~cm}$ polythene bag with proper hole containing mixture of manure, soil and sand in the ratio of 1:2:l and were carefully kept under agro net shade house. Seedlings were watered regularly with sprinklers for providing suitable warm and humid atmosphere.

Seedlings kept under direct sunlight died. Regular measurement notes of saplings were taken to observe its growth. To execute the mean and standard deviation, 25 seedlings were taken for root and shoot growth observation. In between $8-9$ months, seedlings with $92.59 \pm 13.40 \mathrm{~cm}$ shoot height were taken for macro-proliferation.

Each seedling was individually separated carefully with rhizome and root, and transplanted into polythene bag containing the same mixture as stipulated. These separated seedlings were kept for another 6 months under maintenance for healthy growth and then transplanted in the natural habitat (Plate 2).
Table 1. Shoot height and root length of Gigantochloa andamanica (Kurz) Kurz seedlings in different stages.

\begin{tabular}{|c|c|c|c|c|}
\hline $\begin{array}{l}\text { Seedlings } \\
\text { age in } \\
\text { Months }\end{array}$ & $\begin{array}{l}\text { Seed } \\
\text { collected } \\
\text { from wild } \\
\text { for } \\
\text { propagation } \\
\text { (Shoot } \\
\text { height) } \\
\text { Mean } \pm \text { SD }\end{array}$ & $\begin{array}{l}\text { Shoot } \\
\text { height } \\
(25 \\
\text { nos.) } \\
\text { In cm }\end{array}$ & $\begin{array}{l}\text { Seed } \\
\text { collected } \\
\text { from wild } \\
\text { for } \\
\text { propagation } \\
\text { (Root } \\
\text { length) } \\
\text { Mean } \pm \text { SD }\end{array}$ & $\begin{array}{l}\text { Root } \\
\text { length } \\
(25 \\
\text { nos.) } \\
\text { In cm }\end{array}$ \\
\hline About 1 & $6.39 \pm 1.08$ & $5-8$ & $5.01 \pm 1.54$ & $3-6$ \\
\hline $3-8$ & $18.03 \pm 3.01$ & $14-28$ & $5.6 \pm 1.55$ & $4-8$ \\
\hline $5-8$ & $36.03 \pm 6.68$ & $28-45$ & $7.20 \pm 2.51$ & $3-10$ \\
\hline \multicolumn{5}{|c|}{ (Macro- proliferation stage) } \\
\hline $8-10$ & $46.95 \pm 1.77$ & $45-50$ & $8.88 \pm 2.71$ & $4-13$ \\
\hline $12-14$ & $48.9 \pm 2.85$ & $45-54$ & $9.68 \pm 4.38$ & $3-15$ \\
\hline $16-22$ & $66.47 \pm 9.16$ & $50-75$ & $13.15 \pm 5.01$ & $4-20$ \\
\hline
\end{tabular}

\section{Economic value}

Gigantochloa andamanica (Kurz) Kurz is well known for its commercial value. This bamboo is mostly used by tribal especially Jarawas and also by local peoples and Small Scale Industries in Andaman Islands. Jarawas are completely dependent on forest for their livelihood. Each and every product made by them is either from forest or from sea resource. Their artistic and sharp skills are not easy to compete in utilizing bamboos. Bamboo is very much useful in their day to day life. These bamboos are available easily and in finest ways for their daily use.

Leaves of bamboos are used as fodder for elephants and also for thatching. Bamboos are transported from inter-island by using ferry's and truck to small scale industries permitted by Department of Forest Andaman and Nicobar Islands. More than 80 small scale industries are engaged in bamboo works for their livelihood. The range and quantity of bamboos used by small scale industries are permitted in 1500 Nos., 1800 Nos., 2000 Nos., 2400 Nos., 3000 Nos., 3500 Nos., and 5000 Nos. (Anon, 2005). It is often seen that in small scale industries mostly the family members are engaged as employees to make handicrafts. This bamboo is used not only for handicrafts or making household items but also as edibles. It is used as medicine for various ailments by the local people. 


\section{RESULTS AND DISCUSSION}

G. andamanica is growing luxuriantly in the Andaman Islands. Economically this is one of the most valued species in these islands. Recently, due to gregarious flowering, entire clumps in large patches died and a huge population of bamboos is destroyed all over. Seed germination in the natural habitat is good but seedlings survival and growth is nearly $10-20$ percent. And thus the species needs to be conserved through special human attention. Every year in several forest divisions, nurseries are being maintained properly by regular propagation of cuttings, seedlings and then transplanted in the natural habitat. This process continues to balance the population of the species.

During this study the weaker seedlings which were supposed to die in the habitat were collected and planted in polybags in a mixture of Soil: Sand: FYM (2:1:1). These were maintained under controlled shade and rain for their better survival and growth in the polyhouse. By the process of macro proliferation of seedlings, a good numbers of seedlings were multiplied to transplant in the forest with the help and participation of forest department, and the local people. The planted seedlings are monitored frequently and the current survival report estimates $50-60$ percent establishment of the seedlings.

As per our survey, ENM has predicted the accurate distribution of the species. ENM maps locate large patches of flowering in Middle and South-Middle Andaman of high potential area and it is entirely absent in Little Andaman. As per forest statistics, the supply of this bamboo is mainly from Middle and South-Middle only. Due to this event of flowering, it may result in resource deficiency. So, there may be a chance for illegal supply of the resource. Considering the importance of the species, necessary action must be taken by the forest department for the balance of the species regarding conservation and utilization.

\section{ACKNOWLEDGEMENTS}

The authors are thankful to DBT, New Delhi for financial assistance and Department of Forest Andaman and Nicobar Islands for their support. Staff members especially Dineshwar Kumar Sah, Artist and research scholars of Central National Herbarium, Howrah and ANRC Port Blair are duly acknowledged for their help. We are also thankful to Dr. S. Jayakumar, Jawaharlal Nehru Rajkeeya Mahavidhyalaya, Port Blair for his valuable suggestions.

\section{REFERENCES}

Anon, (2005). Working Plan of Middle Andaman Forest Division 2005 2015, Forest Department Andaman and Nicobar Island.
Gupta, M. (1952). Gregarious flowering of Dendrocalamus strictus. Indian Forester, $\quad 78(11), 547-550$

Margules, C. R. and Pressey, R. L. (2000). Systematic conservation planning. Nature 405: 243-253. https://doi.org/10.1038/35012251

McClure, F.A. (1966). The Bamboos: A Fresh Perspective. Harvard University Press, Cambridge, Massachusets.

Ohrnberger, D. (1999). The Bamboos of the World. 252. Elsevier Science B. V. Amsterdam, The Netherlands.

Phillips, J. Steven, Anderson, P. Robert and Schapire E. Robert (2006). Maximum entropy modeling of species geographic distributions. Ecological Modelling 190: 231-259. https://doi.org/10.1016/j.ecolmodel.2005.03.026

Seethalakshmi, K.K. and Kumar, M.S. Muktesh (1998). Bamboos of India: A compendium. Kerela Forest Research Institute, Peechi \& International Network for Bamboo and Rattan, Beijing, Eindhoven, New Delhi.

Vorontsova, S. Maria, Clark, G. Lynn, John Dransfield, Rafael Govaerts and Baker, J. William (2016). World Checklist of Bamboos and Rattans. INBAR technical report no. 37.

Widjaja, E. A. (1987). A revision of Malesian Gigantochloa. Reinwardtia 10(3): 291-380. http://dx.doi.org/10.1016/j.cej.2006.11.001

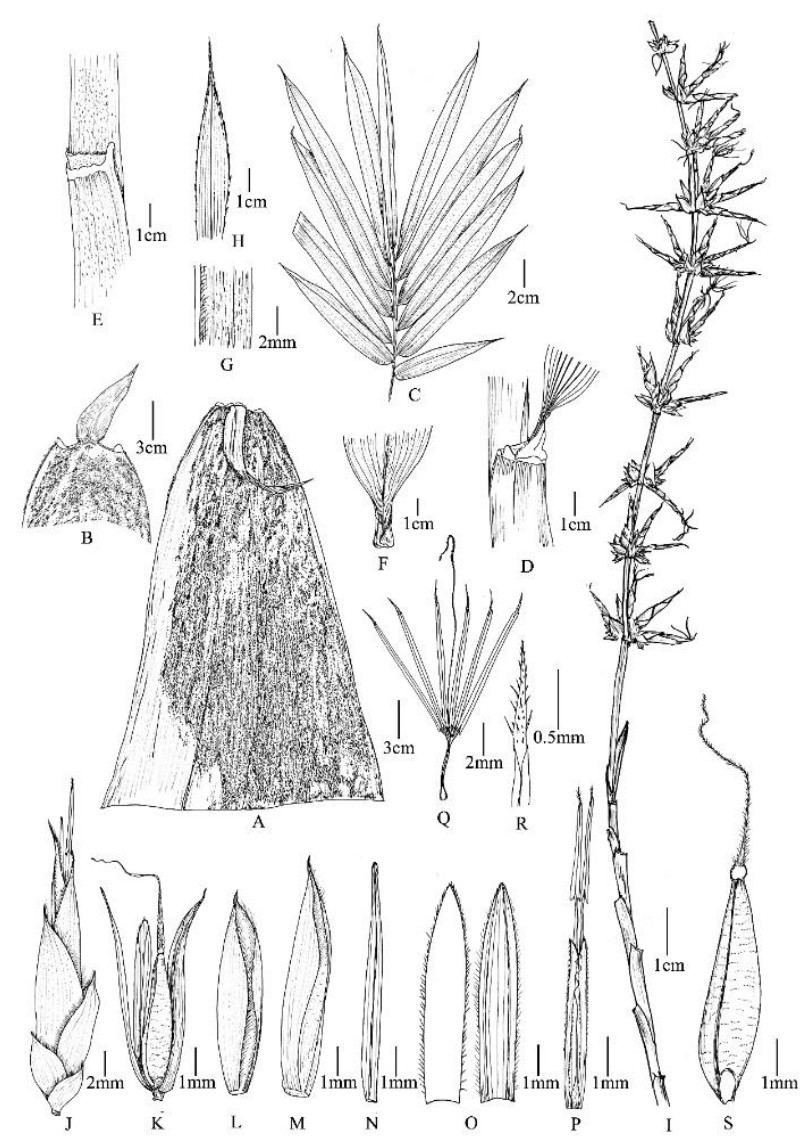

Fig. 1. Gigantochloa andamanica (Kurz) Kurz: A \& B. Culm sheath; C. Leaf twig; D \& E. Leaf sheath; F. Leaf base; G. Abaxial leaf surface; H. Leaf apex; I. Inflorescence; J. Spikelet; K. Single floret; L \& M. Glumes; N. Lemma; O. Palea (dorsal \& ventral); P. Anthers attached with palea; Q. Stamens and pistil; R. Anther apex; S. Caryopsis. 
86 | Field study of gregarious flowering and use of ENM in conservation strategies for Gigantochloa andamanica (Kurz)

Kurz in Andaman Islands (India)

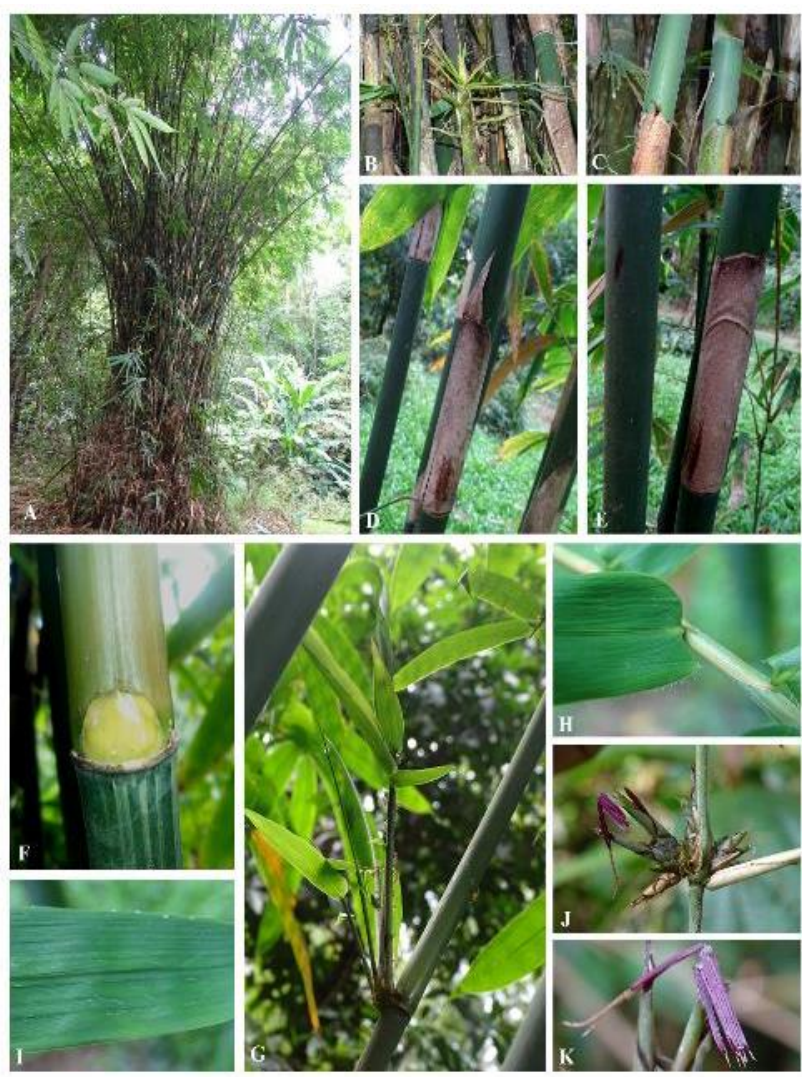

Plate 1. Gigantochloa andamanica (Kurz) Kurz: A. Clump; B. New shoot; C, D Culm sheath; E. Culm sheath ligule; F. Nodal bud; G. Branching pattern; H. Leaf sheath \& leaf margin; I. Hair on leaf upper surface; J. Inflorescence; K. Anthers.
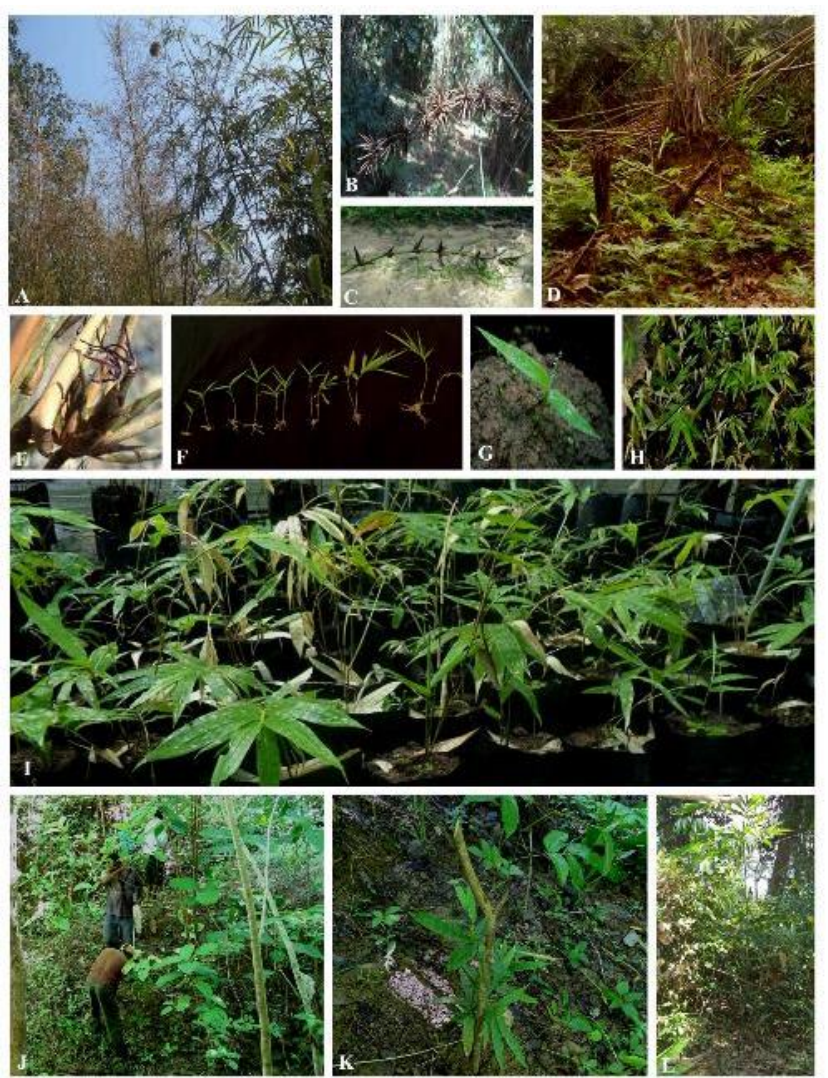

Plate 2. Gigantochloa andamanica (Kurz) Kurz: A. Flowering clumps; B \& C. Inflorescence; D. Wild seedling growing under dead clumps; E. Spikelet; F. Different seedling stages; $G \& H$. Wild seedlings transferred in polybags; I. Saplings splitted and planted in polybags; J. Reintroduction of saplings in natural habitats; K \& L. Established saplings.

(0) 2019| Published by Plantae Scientia 